\title{
HUBUNGAN INDEKS MASSA TUBUH TERHADAP KUALITAS TIDUR PADA LANJUT USIA DI DESA PENATIH
}

\author{
I.A. Pascha Paramurthi ${ }^{1}$, I Made Dhita Prianthara ${ }^{2}$, Kadek Liza Widya Astari ${ }^{3}$ \\ Program Studi Fisioterapi Fakultas Ilmu-Ilmu Kesehatan, Universitas Bali Internasional \\ paschaparamurthi@iikmpbali.ac.id ${ }^{1}$,dhitaprianthara@iikmpbali.ac.id ${ }^{2}$
}

\begin{abstract}
The elderly population in recent years has experienced a significant increase. The condition and function of the body in the elderly are decreasing so that a person will experience a decrease in physical abilities which can affect body shape. Changes in body composition in the elderly include an increase in fat mass, a decrease in fat-free mass and a decrease in bone mass. These changes can increase and decrease the Body Mass Index (BMI). Sleep disturbance that affects sleep quality is sleep disordered breathing (SDB) and is closely related to a person's BMI level. The higher a person's $B M I$, the worse the quality of sleep, and vice versa. Impaired sleep quality occurs due to decreased metabolism, resulting in accumulation of fat and decreased muscle mass increasing a person's chances of suffering from obesity. This study aims to determine the relationship between body mass index and sleep quality in the elderly. This research is a cross-sectional study. The sampling technique was simple random sampling. The research was conducted in Banjar Paang Kelod, Penatih Village, East Denpasar in June - July 2020. The research sample was 49 elderly people. Body mass was measured by BMI and sleep quality was measured by PSQI (Pittsburgh Sleep Quality Index). Based on the chi-square test, the value of $p=0.043$ ( $p<0.05)$ was obtained, which means that there is a significant relationship between body mass index and sleep quality. There is a relationship between body mass index and sleep quality in the elderly.
\end{abstract}

Keywords $\quad$ : Body Mass Index, Elderly, Sleep Quality

\begin{abstract}
ABSTRAK
Penduduk lanjut usia beberapa tahun terakhir mengalami peningkatan yang signifikan. Kondisi dan fungsi tubuh pada lanjut usia semakin menurun sehingga seseorang akan mengalami penurunan kemampuan fisik yang dapat berpengaruh terhadap bentuk tubuh. Perubahan komposisi tubuh pada lansia berupa terjadi peningkatan massa lemak, penurunan massa bebas lemak dan penurunan massa tulang. Perubahan tersebut dapat meningkatkan dan menurunkan Indeks Massa Tubuh (IMT). Gangguan saat tidur yang mempengaruhi kualitas tidur adalah sleep disordered breathing (SDB) dan sangat terkait dengan tingkat IMT seseorang. Semakin tinggi IMT seseorang maka kualitas tidur makin buruk, begitu sebaliknya. Gangguan kualitas tidur terjadi akibat penurunan metabolisme sehingga mengakibatkan penimbunan lemak dan menurunnya massa otot meningkatkan peluang seseorang menderita obesitas. Penelitian ini bertujuan untuk mengetahui hubungan antara indeks massa tubuh terhadap kualitas tidur pada lanjut usia. Penelitian ini adalah cross-sectional study. Teknik pengambilan sampel dengan simple random sampling. Penelitian dilakukan di Banjar Paang Kelod Desa Penatih Denpasar Timur pada bulan Juni - Juli 2020. Sampel penelitian berjumlah 49 orang lanjut usia. Massa tubuh diukur dengan IMT dan kualitas tidur diukur dengan PSQI (Pittsburgh Sleep Quality Index). Berdasarkan uji chi-square didapatkan nilai $\mathrm{p}=0,043(\mathrm{p}<0,05)$ yang artinya terdapat hubungan yang bermakna antara indeks massa tubuh terhadap kualitas tidur. Ada hubungan antara indeks massa tubuh terhadap kualitas tidur pada lanjut usia.
\end{abstract}

Kata Kunci : Indeks Massa Tubuh, Kualitas Tidur, Lanjut Usia,

\section{PENDAHULUAN}

Peningkatan yang signifikan terjadi beberapa tahun terakhir pada lanjut usia. Jumlah lansia di Indonesia pada tahun 2010 sekitar 4\% dari jumlah penduduk, tahun 2020 sekitar $11 \%$, tahun 2030 sekitar 18\%, tahun 2040 sekitar $23 \%$ dan pada tahun 2050 didapatkan jumlah 
total lansia sekitar $28,68 \%$ dari jumlah penduduk. Indonesia merupakan negara ke-4 yang jumlah penduduknya paling banyak di dunia dan sepuluh besar memiliki penduduk paling tua didunia. Tahun 2020 jumlah kaum lansia di Indonesia akan bertambah 28.800.000 juta jiwa $(11 \%$ dari total populasi) dan menjelang tahun 2050 diperkirakan $22 \%$ warga Indonesia berusia 65 tahun ke atas. Itu berarti semakin hari jumlah penduduk lanjut usia semakin banyak dan butuh solusi khusus untuk mengatasinya (Muwarni, 2011).

Peningkatan jumlah lansia dapat dilihat sebagai suatu aset nasional, namun dapat terlihat juga sebagai problematika sosial yang memerlukan perhatian khusus disebabkan karena siklus kehidupan manusia yaitu mengalami proses penuaan secara biologis. Penurunan kemampuan fisik, mental, keterbatasan interaksi sosial, penurunan produktifitas kerja, masalah kesehatan yang signifikan, merupakan proses penuaan secara biologis (Setyawan, 2017). Bertambahnya usia seseorang akan mengalami penurunan kemampuan fisik yang dapat berpengaruh terhadap bentuk tubuh. Komposisi tubuh pada lansia mengalami perubahan seperti terjadi peningkatan massa lemak, penurunan massa bebas lemak dan penurunan massa tulang. Perubahan komposisi tubuh khususnya peningkatan proporsi dan distribusi lemak tubuh, akan menyebabkan peningkatan akumulasi lemak sentral di abdomen yang mengakibatkan obesitas abdominal atau obesitas sentral. Prevalensi obesitas sentral tingkat nasional sebesar 18,8\%, dimana masih terdapat kecenderungan tetap tinggi saat memasuki lansia yaitu sebesar 23,1\% (kelompok umur 55-64), 18,9\% (kelompok umur 65-74) dan 15,8\% (kelompok 75 tahun keatas) (Setyawan, 2017).

Overweight dan Obesitas merupakan keadaan yang menunjukkan ketidakseimbangan antara tinggi dan berat badan akibat jaringan lemak dalam tubuh sehingga terjadi kelebihan berat badan yang melampaui ukuran ideal (Sudargo, 2018). Penyebab meningkatnya kejadian ini akibat perubahan pola hidup (sedentary life style), pola makan, faktor genetik, dan kurangnya aktivitas fisik/olahraga. Obesitas dapat memicu beberapa penyakit seperti penyakit jantung koroner, diabetes melitus tipe 2, hipertensi, dislipidemia, dan salah satunya dapat mengganggu kualitas tidur
(Sudargo, 2018) Kondisi underweight juga merupakan kondisi yang dialami lansia diakibatkan karena terjadinya penyusutan yaitu hilangnya sejumlah jaringan tanpa lemak di dalam tubuh dalam kondisi normal dimana tubuh tersusun atas lemak, tulang, air, serta jaringan tanpa lemak yang berisi otot dan organ.

Kebutuhan tidur yang tidak terpenuhi akan menimbulkan rasa mengantuk diesok harinya. Mengantuk merupakan faktor resiko terjadinya kecelakaan, jatuh, penurunan stamina serta secara ekonomi mengurangi produktifitas seseorang karena orang mengantuk akan mengalami disorientasi terhadap lingkungan sekitar, selain itu juga kondisi mengantuk akan mengalami kesulitan dalam berkonsentrasi serta merasa lelah sehingga lebih cenderung ingin beristirahat bila dibandingkan untuk bekerja (Wisnu, 2017). Kondisi kurang tidur sering ditemukan dikalangan orang dewasa dan lanjut usia. National Sleep Foundation tahun 2015 mendefinisikan kondisi kurang tidur pada orang dewasa yang tidur $<6$ jam mengalami obesitas dan hanya $22 \%$ orang dewasa yang obesitas dengan jam tidur normal. Baik atau buruknya kualitas tidur dapat dipengaruhi oleh beberapa faktor salah satunya adalah obesitas (Saputra, 2014)

Overweight dan Obesitas dapat menjadi salah satu gangguan saat tidur karena dapat mengganggu pernapasan atau yang sering disebut dengan sleep disordered breathing (SDB) dan sangat terkait dengan tingkat obesitas (Arum, 2014). Prevalensi SDB meningkat seiring dengan meningkatnya obesitas (Peppard et al., 2008). Ketebalan leher merupakan salah satu faktor fisik dalam patogenesis obstructive sleep apnea (OSA) (Kawaguchi et al., 2011).

Berdasarkan Diagnostic and Statistical Manual of Mental Disorders-IV (DSMIV), sekitar 20-49\% populasi dewasa di Amerika Serikat pernah mengalami gejala gangguan tidur dan diperkirakan $10-20 \%$ di antaranya mengalami gangguan tidur kronis. Penduduk di Indonesia, diperkirakan $11,7 \%$ dari jumlah seluruh penduduknya mengalami gangguan tidur pada tahun 2004, data tersebut didapatkan melalui riset internasional yang dilakukan oleh US Census Bureau, International Data Base (Permana, 2017). Persentase tersebut diperkirakan bahwa gangguan tidur akan terus meningkat seiring dengan perubahan pola hidup masyarakat. Kurang tidur yang berkepanjangan 
dapat mengganggu kesehatan fisik yaitu muka pucat, mata sembab, badan lemas dan daya tahan tubuh menurun sehingga mudah terserang penyakit dan gangguan psikis seperti, perubahan suasana kejiwaan, sehingga menjadi lesu, lamban menghadapi rangsangan dan sulit berkonsentrasi (Husada, 2015). Seiring pertambahan usia, perubahan hormonal dan gaya hidup kurang aktif maka risiko obesitas meningkat. Selain itu, bertambahnya usia menyebabkan jumlah otot dalam tubuh cenderung menurun. Massa otot yang lebih rendah menyebabkan penurunan metabolisme. Obesitas menyebabkan meningkatnya kebutuhan kalori dan penimbunan lemak sehingga menyebabkan risiko terjadinya gangguan kualitas tidur (Yonesi, 2017). Kondisi dimana kurang tidur dapat meningkatkan peluang seseorang menderita obesitas dan gangguan pernafasan saat tidur (Rahe, 2015)

Berdasarkan pemaparan studi tentang pentingnya kualitas tidur serta hubungannya terhadap obesitas pada lanjut usia, "Hubungan antara Indeks Massa Tubuh terhadap Kualitas Tidur pada Lanjut Usia di Banjar Paang Kelod Desa Penatih Denpasar Timur."

\section{METODE}

Penelitian ini merupakan penelitian observasional dengan menggunakan rancangan cross sectional study. Populasi target dalam penelitian ini adalah lanjut usia di Banjar Paang Kelod Desa Penatih Denpasar Timur. Populasi terjangkau dalam penelitian ini adalah lanjut usia yang IMT normal, overweight dan obesitas di Banjar Paang Kelod Desa Penatih Denpasar Timur. Penelitian dilakukan pada bulan JuniJuli 2020.

Sampel adalah yang memenuhi kriteria inklusi dan eksklusi. Kriteria inklusi : a) Lansia di Desa Penatih Banjar Paang Kelod Kecamatan Denpasar Timur; b) Sehat jasmani dan rohani; c) Berumur 60-74 tahun; d) Subjek dengan kategori normal, overweight dan obesitas; e) Kooperatif dan dapat mengerti perintah verbal; f) Bersedia menjadi subjek penelitian dan menandatangani informed consent. Kriteria eksklusi : a) Sampel minum obat tidur; b) Mengalami gangguan mental. Kriteria pengguguran : a) Mengundurkan diri pada saat penelitian berlangsung; b) Mengalami cedera atau sakit saat penelitian berlangsung.
Penelitian ini menggunakan rumus besar sampel yang digunakan adalah total sampling. Populasi lanjut usia di Banjar Paang Kelod Desa Penatih Denpasar Timur berjumlah 60 orang kemudian dilakukan seleksi sesuai dengan kriteria inklusi dan eksklusi didapatkan 49 sampel yang sesuai dengan kriteria. Teknik pengambilan sampel pada penelitian ini dengan menggunakan teknik purposive sampling sesuai dengan kriteria inklusi dan eksklusi. Alat ukur dalam penelitian ini adalah PSQI (Pittsburgh Sleep Quality Index) untuk mengukur kualitas tidur dengan nilai validitas 0,89 dan pengukuran massa tubuh menggunakan Indeks Massa Tubuh dengan nilai validitas mempunyai nilai sensitivitas $(51,6 \%$ $72 \%$ ) dan spesifisitas $(44,8 \%-77,7 \%)$.

\section{HASIL}

Karakteristik Responden

Tabel 1. Karekteristik Responden

\begin{tabular}{ccc}
\hline Karakteristik Responden & $\mathrm{f}$ & $\%$ \\
\hline Kelompok usia & 49 & 100 \\
$60-64$ tahun & 10 & 20,4 \\
$65-69$ tahun & 22 & 44,9 \\
$70-74$ tahun & 17 & 34,6 \\
Jenis kelamin & & \\
Laki-laki & 19 & 38,8 \\
Perempuan & 30 & 61,2 \\
\hline
\end{tabular}

Pada Tabel 1 data karakteristik responden diketahui bahwa responden terbanyak ada pada kelompok usia 65-69 tahun yaitu sebanyak 22 responden (44,9\%), kemudian untuk karakteristik responden berdasarkan jenis kelamin yaitu sebanyak 30 orang $(47,5 \%)$ perempuan dan 19 orang $(52,5)$ laki-laki.

Tabel 2. Distribusi responden berdasarkan kategori IMT dan Kualitas Tidur

\begin{tabular}{lcc}
\hline Distribusi Responden & $\mathrm{f}$ & $\%$ \\
\hline Kategori IMT & 49 & 100 \\
Underweight & 8 & 16,3 \\
Normal & 10 & 20,4 \\
Overweight & 11 & 22,4 \\
Obesitas & 20 & 40,8 \\
Kualitas Tidur & & \\
Baik & 22 & 44,9 \\
Buruk & 27 & 55,1 \\
\hline
\end{tabular}

Pada Tabel 2 menunjukkan responden yang memiliki kategori IMT underweight sebanyak 8 responden $(16,3 \%)$ normal sebanyak 10 responden $(20,4 \%)$ overweight sebanyak 11 responden $(22,4 \%)$ dan obesitas sebanyak 20 responden $(40,8 \%)$. Data juga menunjukkan 
responden yang mengalami kualitas tidur baik sebanyak 22 responden (44,9\%), sedangkan yang mengalami kualitas tidur buruk sebanyak 27 responden $(55,1 \%)$.

Hubungan Antara IMT dengan Kualitas Tidur

Tabel 3. Tabel Silang IMT Dengan Kualitas Tidur

\begin{tabular}{|c|c|c|c|c|c|c|c|}
\hline \multirow{3}{*}{ Kategori IMT } & \multicolumn{4}{|c|}{ Kualitas Tidur } & \multicolumn{2}{|c|}{ Total } & Nilai \\
\hline & \multicolumn{2}{|c|}{ Baik } & \multicolumn{2}{|c|}{ Buruk } & \multirow[b]{2}{*}{$\mathrm{n}$} & \multirow[b]{2}{*}{$\%$} & \\
\hline & $\mathrm{f}$ & $\%$ & $f$ & $\%$ & & & \\
\hline Underweight & 6 & 12,2 & 2 & 4,1 & 8 & 16,3 & \multirow{4}{*}{0,029} \\
\hline Normal & 7 & 14,3 & 3 & 6,1 & 10 & 20,4 & \\
\hline Overweight & 4 & 8,2 & 7 & 14,3 & 11 & 22,4 & \\
\hline Obesitas & 5 & 10,2 & 15 & 30,6 & 20 & 40,8 & \\
\hline Jumlah & 22 & 57,4 & 27 & 42,6 & 49 & 100 & \\
\hline
\end{tabular}

Pada Tabel 3 dapat dilihat responden pada kualitas tidur baik paling banyak pada kategori IMT normal terdapat 7 orang $(14,3 \%)$ dan yang mengalami kualitas tidur buruk paling banyak pada kategori IMT obesitas yaitu sebanyak 15 orang $(30,6 \%)$.

\section{PEMBAHASAN}

\section{Karakteristik Responden}

Responden dalam penelitian ini adalah lanjut usia yang dipilih dengan metode purposive sampling sebanyak 49 orang. Data karakteristik responden diambil berdasarkan umur, jenis kelamin dan pekerjaan.

Pada Tabel 1. menunjukkan bahwa responden terbanyak ada pada kelompok usia 65 - 69 tahun yang berjumlah 22 orang (44,9\%), tidak berbeda jauh dengan kelompok usia 70 74 tahun yang berjumlah 17 orang $(34,6 \%)$ dan kelompok usia 60 - 64 tahun yang berjumlah 10 orang $(20,4 \%)$. Hal ini menunjukan bahwa cukup banyak lansia mengalami kelebihan berat badan baik itu overweight maupun obesitas. Kelebihan berat badan baik itu overweight maupun obesitas timbul karena banyak penyebab, salah satunya adalah tidak seimbangnya asupan energi dari makanan dan minuman dengan energi yang dikeluarkan untuk beraktivitas. Saat ini lanjut usia cenderung mengalami penurunan dalam aktivitas fisik maupun olahraga sehingga kecenderungan mengalami kelebihan berat badan akan lebih besar (Noviantio, 2012). Tabel 1 memperlihatkan bahwa responden berjenis kelamin perempuan lebih banyak yaitu berjumlah 30 orang $(61,2 \%)$ dan responden berjenis kelamin laki-laki yang berjumlah 19 orang $(38,8 \%)$. Berdasarkan data tersebut menunjukkan bahwa jenis kelamin perempuan lebih banyak yang mengalami obesitas dan overweight. Sejalan dengan penelitian Galetta (2005) di mana secara rata-rata laki-laki mempunyai massa otot yang lebih banyak dari wanita. Di mana laki- laki memakai lebih banyak kalori dibandingkan wanita bahkan saat istirahat. Di mana otot memiliki sifat membakar kalori lebih banyak daripada tipe-tipe jaringan yang lain. Dengan demikian perempuan lebih mudah bertambah berat badan dibandingkan laki-laki walaupun dengan asupan kalori yang sama (Teresa, 2018)

Tabel 2 menunjukkan data responden yang memiliki kategori IMT underweight sebanyak 8 responden $(16,3 \%)$ normal sebanyak 10 responden $(20,4 \%)$ overweight sebanyak 11 responden $(22,4 \%)$ dan obesitas sebanyak 20 responden $(40,8 \%)$. Dari hasil analisis univariat ini dapat dilihat bahwa cukup banyak lanjut usia di Banjar Paang Kelod Desa Penatih yang menderita kelebihan berat badan. Hal ini bisa disebabkan oleh banyak penyebab, antara lain perilaku makan yang tidak baik, kelainan neurogenik, faktor genetik, faktor hormonal, faktor metabolit, dan dampak dari penyakit lain (Manik, 2011).

Data juga menunjukkan responden yang mengalami kualitas tidur baik sebanyak 22 responden $(44,9 \%)$, sedangkan yang mengalami kualitas tidur buruk sebanyak 27 responden $(55,1 \%)$. Hal ini menunjukan bahwa kualitas 
tidur buruk cukup sering dialami oleh mereka yang memiliki kelebihan berat badan khususnya pada lanjut usia di Banjar Paang Kelod Desa Penatih. Sesuai dengan kajian pustaka yang menyatakan bahwa seseorang dengan berat badan berlebih mempunyai resiko (Sulistyani, 2012)

\section{Hubungan Antara IMT dengan Kualitas Tidur}

Pada Tabel 3 dapat dilihat responden pada kualitas tidur baik paling banyak pada kategori IMT normal terdapat 7 orang $(14,3 \%)$ dan yang mengalami kualitas tidur buruk paling banyak pada kategori IMT obesitas yaitu sebanyak 15 orang $(30,6 \%)$. Hasil penelitian setelah dilakukan uji chi-square untuk mencari hubungan antara indeks massa tubuh dengan kualitas tidur pada lansia di Banjar Paang Kelod Desa Penatih Denpasar Timur diperoleh nilai $p$ sebesar 0,029 ( $p<0,05)$. Berdasarkan hasil uji secara statistik ini menunjukkan bahwa terdapat hubungan yang bermakna antara indeks massa tubuh dengan kualitas tidur pada lansia di Banjar Paang Kelod Desa Penatih Denpasar Timur.

Kualitas tidur banyak ditemukan baik pada responden yang mengalami overweight maupun responden yang mengalami obesitas. Hasil tabel silang IMT dengan kualitas tidur pada tabel 3 menunjukkan responden pada kategori IMT underweight terdapat 6 orang yang kualitas tidur baik dan 2 orang kualitas tidur buruk, IMT normal terdapat 7 orang yang kualitas tidur baik dan 3 orang kualitas tidur buruk, pada kategori IMT overweight terdapat 7 orang yang kualitas tidur buruk dan 4 orang kualitas tidur baik, kemudian pada kategori IMT obesitas responden yang kualitas tidur buruk sebanyak 15 orang dan yang kualitas tidur baik sebanyak 5 orang. Hasil uji chi-square yang dilakukan juga menunjukkan hasil $p$ sebesar 0,029 yang lebih kecil dari nilai standar $0,05 \quad(p<\alpha)$. Hal tersebut menunjukkan bahwa terdapat hubungan yang bermakna antara indeks massa tubuh dengan kualitas tidur pada lanjut usia Banjar Paang Kelod Desa Penatih Denpasar Timur.

Sejalan dengan penelitian yang dilakukan oleh Sulistyani tahun 2012 kualitas tidur tidak dapat terlepas dari kondisi fisik seseorang. Mereka yang tergolong dalam IMT kurus tidak akan mengalami sleep apnea, sehingga menjadikan mereka lebih mudah jatuh tidur dan merasa nyenyak saat tidur, serta dapat memberikan efek pada individu tersebut, seperti merasa segar saat bangun, tidak mengantuk saat beraktivitas, dan tidak merasakan keletihan saat beraktivitas. Apnea saat tidur ini merupakan suatu kelainan karakteristik pernafasan abnormal berupa berhentinya nafas sesaat selama tidur. Hal ini menunjukkan bahwa mereka yang termasuk dalam kategori IMT kurus lebih cenderung memiliki kualitas tidur yang baik. Sehingga dapat disimpulkan jika semakin tinggi status IMT (obesitas) maka akan semakin buruk kualitas tidurnya. Hasil penelitian tersebut juga tidak bertolak belakang dengan penelitian yang dilakukan oleh Sulistyani (2012) yang telah membuktikan bahwa mereka yang mengalami obesitas dapat memiliki risiko yang lebih besar untuk mengalami kualitas tidur yang buruk.

Penelitian ini sejalan dengan penelitian yang dilakukan oleh Damayanti (2019) dimana dalam penelitiannya terhadap suatu populasi menunjukkan Indeks Massa Tubuh (IMT) yang lebih tinggi pada responden tidur kurang dari 7 jam perhari. Selain itu Astuti (2018) juga mengkonfirmasi waktu tidur yang lebih lama yang tidak disertai dengan aktivitas fisik ataupun olahraga dan pengurangan asupan energi juga bisa menaikkan IMT. Menurut Yonesi tahun 2017 kondisi kualitas tidur yang menurun disebabkan antara lain oleh penurunan durasi tidur, perubahan pola tidur, kesulitan memulai tidur, dan pola tidur yang sangat berbeda saat hari-hari biasa dan akhir pekan. Hasil penelitian ini ditunjang oleh penelitian yang dilakukan Park dkk (2018) dimana ingin mengetahui hubungan antara kualitas tidur dan kategori BMI didapatkan hasil kualitas tidur yang buruk cenderung berhubungan dengan obesitas, dan lebih lebih dominan pada subkelompok wanita dibandingkan subkelompok pria.

Berdasarkan literatur, overweight dan obesitas menyebabkan meningkatnya kebutuhan kalori dan penimbunan lemak sehingga dapat beresiko terjadinya gangguan kualitas tidur, akibat efek mekanis dan kimiawi yang ditimbulkannya terhadap struktur dan fungsi jalan nafas (Romero-Corral, 2010). Penimbunan lemak yang berlebihan di jalan nafas atas dapat mengakibatkan penyempitan jalan nafas yang kemudian dapat mengakibatkan penutupan jalan nafas pada saat jaringan otot di sepanjang jalan nafas sedang relaksasi sewaktu tidur. Penimbunan lemak yang berlebihan di bawah 
diafragma dan di dalam dinding dada akan menekan paru sehingga mengganggu upaya ventilasi pada saat tidur.

Pada kondisi obesitas terjadi peningkatan kadar hormon ghrelin dan penurunan kadar hormon leptin. Leptin tidak hanya berperan pada sistem oreksin namun juga berperan dalam kontrol ventilasi. Kadar dan fungsi leptin yang tidak adekuat pada kondisi obesitas diduga berdampak pada gangguan pada kontrol ventilasi. Leptin bersama adipokin lainnya, seperti TNF- $\alpha$ dan interleukin-6 dapat mengakibatkan depresi aktivitas susunan saraf pusat yang mengatur saraf-otot pada saluran nafas. Gangguan pernafasan tersebut menyebabkan terhentinya pernafasan sehingga seseorang akan terbangun dan durasi tidur dan kualitas tidurnya akan terganggu. Kualitas tidur yang buruk kembali menjadi faktor resiko bagi peningkatan berat badan dan obesitas. Penelitian yang dilakukan oleh Piskáčková dkk tahun 2010 mendapatkan bahwa kurang tidur menyebabkan penurunan kadar leptin sebesar $18 \%$ dan peningkatan kadar ghrelin sebesar 28\%. Penelitian ini juga didukung oleh Vargas PA et al (2014) yang menyebutkan bahwa gangguan tidur, dibandingkan durasi tidur, diprediksi berperan menyebabkan overweight.

\section{KESIMPULAN}

Berdasarkan tujuan dan hasil penelitian diatas, maka dapat disimpulkan ada hubungan antara indeks massa tubuh dengan kualitas tidur pada lanjut usia di Banjar Paang Kelod Desa Penatih Denpasar Timur.

\section{UCAPAN TERIMAKASIH}

Ucapan terimakasih disampaikan kepada Bapak Kepala Dinas Banjar Paang Kelod, warga yang telah membantu dalam proses penelitian dan teman-teman dosen Universitas Bali Internasional yang turut membantu serta semua pihak yang telah memberikan banyak bantuan dalam menyelesaikan penelitian ini.

\section{DAFTAR PUSTAKA}

Arum, W. D. M., Wiboworini, B., \& Kusumawati, R. (2014). The association between body mass index (BMI) and neck circumference with sleep quality. Nexus

Kedokteran
Astuti, G. A. K. R. W. (2018). Hubungan Kebiasaan Olahraga, Kebiasaan Mengonsumsi Fast Food Dengan Kejadian Obesitas Pada Remaja Di Smp Bintang Persada Di Denpasar (Doctoral dissertation, Jurusan Gizi).

Husada, S. K. (2015). Hubungan Tingkat Kecemasan dengan Kualitas Tidur Penderita Asma di RSUD Kabupaten Karanganyar.

Kawaguchi, Y., Fukumoto, S., Inaba, M., Koyama, H., Shoji, T., Shoji, S., \& Nishizawa, Y. (2011). Different impacts of neck circumference and visceral obesity on the severity of obstructive sleep apnea syndrome. Obesity, 19(2), 276-282.

Manik, C. P. N. (2011). Hubungan Jumlah Jam Tidur dengan Indeks Massa Tubuh pada Mahasiswa Fakultas Kedokteran Universitas Sumatera Utara.

Murwani, A., \& Priyantari, W. (2011). Gerontik Konsep Dasar dan Asuhan Keperawatan Home Care dan Komunitas. Fitramaya, Yogyakarta.

National Sleep Foundation. Amerika. (2011). (Online), www.sleepfoundation.org diakses pada tanggal 7 September 2020).

Noviantio, S. (2012). Hubungan Kelebihan Berat Badan Dan Aktifitas Fisik Terhadap Menarche Dini Pada Siswi Sekolah Dasar Di Kecamatan Baleendah.

Park, S. K., Jung, J. Y., Oh, C. M., McIntyre, R. S., \& Lee, J. H. (2018). Association between sleep duration, quality and body mass index in the Korean population. Journal of Clinical Sleep Medicine, 14(8), 1353-1360.

Peppard, P. E., Young, T., Barnet, J. H., Palta, M., Hagen, E. W., \& Hla, K. M. (2013). Increased prevalence of sleep-disordered breathing in adults. American journal of epidemiology, 177(9), 1006-1014.

Permana, M. G. C. (2013). Insomnia and Correlation with Psychosocial Factors in Primary Health Care. E-Jurnal Medika Udayana, 237-253.

Piskáčková, Z. (2010). The association between sleep duration and body weight in adults. Health Education : International experience; 4 : 207-213.

Rahe, C., Czira, M. E., Teismann, H., \& Berger, K. (2015). Associations between poor sleep quality and different measures of 
obesity. Sleep medicine, 16(10), $1225-$ 1228.

Romero-Corral, A., Caples, S.M., LopezJimenez, F. and Somers, V.K., 2010. Interactions between obesity and obstructive sleep apnea: implications for treatment. Chest, 137(3), pp.711-719.

Saputra, M. A., \& Yuniarti, F. A. (2014). Studi Komparasi Kualitas Tidur Anak Obesitas dan Tidak Obesitas Pada Anak di SD Negeri Serang Sendangsari Pengasih Kulon Progo (Doctoral dissertation, STIKES'Aisyiyah Yogyakarta).

Setyawan, R., Zaidah, L., \& Fatmawati, V. (2017). Pengaruh Terapi Massage Punggung dan Senam Lansia terhadap Kualitas Tidur pada Lansia.

Sudargo, T., Freitag, H., Kusmayanti, N. A., \& Rosiyani, F. (2018). Pola makan dan obesitas. UGM press.
Sulistiyani, C. (2012). Beberapa Faktor Yang Berhubungan Dengan Kualitas Tidur Pada Mahasiswa Fakultas Kesehatan Masyarakat Universitas Diponegoro Semarang. Jurnal Kesehatan Masyarakat Universitas Diponegoro, 1(2), 18762.

Teresa, S., Widodo, S., \& Winarni, T. I. (2018). Hubungan body mass index dan persentase lemak tubuh dengan volume oksigen maksimal pada dewasa muda (Doctoral dissertation, Faculty of Medicine).

Vargas, P.A., Flores, M. and Robles, E., (2014). Sleep quality and body mass index in college students: the role of sleep disturbances. Journal of American College Health, 62(8), pp.534-541.

Yonesi, E.F. and Aswar, A., (2017). Hubungan obesitas dengan kualitas tidur pada usia dewasa akhir (Doctoral dissertation, Trisakti University). 